\title{
Influence of Ocimum gratissimum Leaves Supplement on Growth Indices and Blood Constituents of Goats Fed Sweet Potato Peels with Cashew Nut Shell
}

\author{
M. I. Okoruwa ${ }^{1 *}$, C. A. Igene ${ }^{2}$ \\ ${ }^{1}$ Department of Animal Science, Ambrose Alli University, Ekpoma, Nigeria \\ ${ }^{2}$ Department of Agricultural Economics and Extension, Ambrose Alli University, Ekpoma, Nigeria \\ Email: ${ }^{*}$ odionokos@yahoo.com, ${ }^{*}$ okosmich@gmail.com
}

Received 15 July 2015; accepted 21 September 2015; published 24 September 2015

Copyright (C) 2015 by authors and Scientific Research Publishing Inc.

This work is licensed under the Creative Commons Attribution International License (CC BY).

http://creativecommons.org/licenses/by/4.0/

c) (i) Open Access

\section{Abstract}

The study was carried out to determine the influence of sweet potato peels and cashew nut shell supplemented with Ocimum gratissium leaves, using growth indices and blood constituents by goats. Eighteen goats with an average weight of $8.11 \mathrm{~kg}$ and aged between 8 and 9 months old were allotted to three dietary treatments with six animals per treatment in a complete randomized design. The compared diets which comprised combination of sweet potato peels and cashew nut shell with concentrate respectively were in different ratios which included diet I (30:25:45), diet II (25:30:45) and diet III (20:35:45). Each goat also received 8 grams of Ocimum gratissium leaves as supplement in the diet. The results showed that average feed intake $(6.42 \mathrm{~kg})$ and fed conversion ratio (2.15) were highest in diet I and significantly different from other diets. Diet II had the highest significant $(P<0.05)$ values in final body weight $(12.01 \mathrm{~kg})$, average total weight gain $(3.89 \mathrm{~kg})$, packed cell volume $(29.46 \%)$, haemoglobin $(10.96 \%)$, red blood cell $\left(9.84 \times 10^{3} / \mathrm{L}\right)$, lymphocytes $(56.01 \%)$, monocytes $(1.06 \%)$, total protein $(7.65 \mathrm{~g} / \mathrm{dl})$, albumin $(3.58 \mathrm{~g} / \mathrm{dl})$, globulin $(4.07 \mathrm{~g} / \mathrm{dl})$ and triglyceride $(2.29 \mathrm{mmol} / \mathrm{L})$. White blood cell $\left(7.01 \times 10^{3} / \mathrm{L}\right)$, neutrophils $(49.82 \%)$, cholesterol $(42.34 \mathrm{mmol} / \mathrm{L})$, creatnine $(1.59 \mathrm{mg} / \mathrm{dl})$ and urea $(18.29 \mathrm{mg} / \mathrm{dl})$ were $(\mathrm{P}<0.05)$ best in diet III, whereas initial bodyweight, average daily weight gain, eosinophils and basophils were not significantly different $(\mathrm{P}<0.05)$. It is concluded that diet II has the potential to enhance growth rate and blood constituents of goats.

\footnotetext{
${ }^{*}$ Corresponding author.
}

How to cite this paper: Okoruwa, M.I. and Igene, C.A. (2015) Influence of Ocimum gratissimum Leaves Supplement on Growth Indices and Blood Constituents of Goats Fed Sweet Potato Peels with Cashew Nut Shell. Open Journal of Animal Sciences, 5, 394-401. http://dx.doi.org/10.4236/ojas.2015.54041 


\section{Keywords}

\section{Potato Peels, Cashew Shell, Ocimum, Growth, Blood, Goats}

\section{Introduction}

Animal protein is paramount to the existence of man and its quality and quantity are of utmost importance. Ibitoye et al. [1] report that the demand for animal protein origin in Nigeria is greater than the supply. Thus, there is acute shortage of animal protein in the diet of many Nigerians. However, animal protein deficiency problem in Nigeria is centred on the problem of inadequate livestock production in Nigeria. Okoruwa et al. [2] report that, if adequate attention is given to livestock production in Nigeria, animal protein can immediately meet the need and guarantee a future of continuous supply for the sustenance of humanity. Goats have been identified as one of the conventional livestock that is capable of solving the problem of low protein intake in Nigeria. Therefore, there is a need to encourage the production of goats by making breeding and fattening stock readily available for intending goat farmers. This can be achieved through rearing and management, although ruminant nutrition bewildering ranges of responses and problems are always encountered. The roles presently played by goats in terms of contributing to nutritional values, meat yield and sources of income need to be sustained, because its production is one of the ways to ensure sustainable meat and milk products from ruminant livestock farming in Nigeria [3]. These characteristics of goats generate surge of interest in the livestock production nowadays. To encourage this interest, knowledge of their health with growth performance is considered as great importance for the successful management of goats.

Notwithstanding, one of the major threaten problems facing ruminant production, most especially goats is the inability to meet the nutritional requirement of the goats. The escalating rise in conventional feed prices and the scarcity with the fluctuating quantity and quality of year round forage supply have been the major constrain hampering ruminant livestock production industry in Nigeria. Thus, this has geared the effort of many livestock farmers to popularize the search for alternative feed sources that are derived from unconventional feedstuffs and agro-industrial by-products. Sweet potato (Ipomea batatas) peel is classified as an agro-industrial by-product that is rich in energy source for livestock. It has a major influence on reducing the problem of inadequate forages for livestock consumption during the dry season. Sweet potato peels limitations involve high sugaring content and anti-nutritional factors that make the processing pre-requisite to use as feeds [4].

However, cashew (Anacardium occidentiale) nut shell is a by-product obtained from the processing of cashew kernel. Cashew nut shell has significant values as a feed while lowering the cost of feed input [5]. Since ruminants are essentially recyclers, the use of cashew nut shell is particularly suited to ruminants that will ultimately produce high quality products from the feeding of cashew nut shell that may otherwise be discarded as waste. The usage of cashew nut shell is limited due to poor understanding of its nutritional and economic value as well as their proper use in ruminant rations. So, environmentally as well as economically crop by-products will continue to become more important as ingredients in ruminant rations. The problems associated with the use of cashew nut shell in ruminants rations are its hardness, oily nature and high acidity which can be reduced with the level of inclusion in the diets and processing methods. Okolo et al. [5] report that lf cashew nut shell is to be used more than $30 \%$ inclusion level in ruminant diet, the ration will require concentrate that is low in fat but rich in other nutrients to augment the ration. Ocimum gratissimum is a plant that belongs to Lamiaceae family. It is known as food spice and traditional herb, which has been recommended for treatment of various diseases such as upper respiratory tract infection and diarrhoea. The leaves contain nutrients, antioxidants and healthy proteins which can be used as supplement in livestock feeds to augment the nutrient content and reduce the chances of disease infection in ruminants [6]. Growth indices and blood parameters such as haematological and biochemical values have been known to be good in assessing the nutritional and physiological status of animals. Hence, this study determines the supplementation of Ocimum gratissimum leaves on growth indices and blood constituents of goats fed sweet potato peels with cashew nut shell.

\section{Materials and Methods}

Study Site: The study was carried out at Small Ruminant Unit of the Teaching and Research Farm, Ambrose 
Alli University, Ekpoma, Nigeria. Ekpoma is within the South-South geo-political Zone of (Long. $6.09^{\circ} \mathrm{E}$ and Lat. $6.42^{\circ} \mathrm{N}$ ) Nigeria that has a prevailing tropical climate. The area is characterized by long rain fall pattern and short periods of dry season with mean annual rainfall and temperature of about $1556 \mathrm{~mm}$ and $30 \%$ respectively.

Experimental Diets: Fresh sweet potato peels were collected from the processing points within Ekpoma, mixed, washed, sun dried and crushed. Cashew nuts were collected within the Teaching and Research Farm; the raw cashew nuts were washed manually with sand and water. Thereafter, they were soaked, steamed and dried in the sun for 4 to 5 days. The nuts were then roasted to facilitate the release of the kernels when shelling was done. The shelling was done manually with a locally fabricated Sheller. The cashew nuts shell, after shelling were dried in the sun and crushed. Concentrate ingredients of the following $50 \%$ brewer's dry gran, $35 \%$ wheat offal , $10 \%$ rice bran, $1.50 \%$ vitamin, $2.00 \%$ bone meal, $1.00 \%$ limestone and $0.50 \%$ salt with calculated $16.15 \%$ crude protein and $1930.50 \mathrm{Kcal} / \mathrm{kg}$ metabolizable energy was formulated. Ocimum gratissimum leaves that serve as supplement were obtained from the plant and sun dried. The dried leaves were milled in a hammer -mill to pass through a $20 \mathrm{~mm}$ screen into powder form to reduce selection when mixed with diets.

However, the three compared experimental diets (I, II and III) which comprised the combination of sweet potato peels and cashew nut shell with concentrate respectively were in different ratios which include diets I (30:25:45), II (25:30:45) and III (20:35:45). The experimental diets were offered as ration at the rate of 5\% (DM basis) of their body weight. Each goat received 8 grams of Ocimum gratissimum leaves powder in their respective diets.

\subsection{Experimental Animals and Management}

Eighteen growing male West African dwarf goats aged between 8 to 9 months old with an average body weight of $8.00 \pm 0.11 \mathrm{~kg}$ were used for the study. The animals were purchased from an open livestock market within Ekpoma metropolis in Edo State, Nigeria. The goats were randomly allocated to the three dietary treatments in a completely randomized design. Each treatment was replicated with six animals. The goats were reared and maintained in individual pen within a properly ventilation. The pen of each animal was clearly labelled for proper identification of each goat. The diets with 8 grams of Ocimum gratissimum leaves powder was fed to each goat once daily at $8.00 \mathrm{a} . \mathrm{m}$. in the morning. Water and salt lick were also provided to the animal ad libitum.

Strict hygiene condition was maintained in the confinement by regular cleaning of the pens and washing of the feeding and water troughs on daily basis. The goats were given prophylactic treatment against parasites and diseases before the commencement of the study that lasted for 12 weeks after 2 weeks of acclimatization. The quantity of feed supply were weighed every morning and the left over were also weighed to compute feed intake. Live weight measures of the animals were taken on weekly basis. Data derived from the daily feed intake and daily weight gains were computed and feed conversion ratio was calculated as the ratio of feed intake over the body weight gain.

\subsection{Blood Collection and Analysis}

Blood samples were collected from each goat by the jugular-veniputure at the last day of the study before terminating the experiment. The animals were bled in the morning prior to feeding and average of $7 \mathrm{ml}$ of blood sample was transferred immediately into sterile sample bottles containing ethylene-diamine-tetra-acetic acid (EDTA) which was used for the haematological analysis. Another $4 \mathrm{ml}$ of blood sample was collected into a screw-capped test tube and allowed to clot and serum expressed. The serum was harvested for biochemical analysis.

However, haematological analysis of packed cell volume (PCV), haemoglobin (Hb), red blood cell (RBC), total white blood cell (WBC) and the differential counts were carried out according to the methods described by [7]. Serum biochemical analysis such as determination of total protein, albumin, triglyceride, cholesterol, urea and creatinine were done using the methods according to [8]. Globulin was calculated as the difference between total protein and albumin.

\subsection{Chemical and Statistical Analyses}

Samples of the experimental feeds were analysed for proximate analysis using the procedure of [9].

Data generated from the growth, haematological and serum biochemical parameters were subjected to analy- 
sis of variance (ANOVA). Significant difference between treatments means were separated using Duncan's Multiple Range Test [10].

\section{Results and Discussion}

The proximate composition (\%DM) of sweet potato peels, cashew nut shell, Ocimum gratissimum leaves and concentrate are shown in Table 1. Dry matter values ranged from $81.50 \%$ in Ocimum gratissimum leaves to $92.20 \%$ in cashew nut shell. The differences observed in their dry matter could be due to the ingredient of the fed that were characteristically different in dry matter content. Sweet potato peels $(6.40 \%)$, cashew nut shell $(5.50 \%)$ and Ocimum gratissimum leaves (4.43\%) were relatively low in crude protein than the critical level of $8 \%$ for ruminant, as reported by [11] necessary to provide minimum ammonia levels required by rumen micro-organism to support optimum activity [12]. Hence, $16.15 \%$ for concentrate was used in the ration which was fairly high protein source to raise the overall protein content of the ration to facilitate maximum dietary crude fibre digestion in the rumen the rumen. Crude fibre values that ranged between $4.00 \%$ and $22.75 \%$ were highest in cashew nut shell and lowest in sweet potato peels. This indicated that cashew nut shell had higher fibre content than other feeds used in the study. The ether extract of $39.25 \%$ for cashew nut shell was rather high, this high content might reduced methane emission because [12] reported a 33\% reduction in methane emission when $4 \%$ canola oil was added to a diet containing $85 \%$ concentrate in feedlot. It could also be translated to corresponding high carotene content [13]. On the other hand, this high level of fat content could depress fibre digestion, since [12] reported a depression in fibre digestion when fat level exceeded $5 \%-6 \%$ in ruminant rations. Thus, sweet potato peels $(6.00 \%)$, Ocimum gratissimum leaves $(2.70 \%)$ and concentrate $(1.14 \%)$ ether extract were low, so as to reduce the fat content of the ration to recommended levels. The ash content of cashew nut shell (1.09\%) and Ocimum gratissimum leaves (1.15\%) were low which could probably balance up by sweet potato peels (7.50\%) and concentrate (7.89\%). The nitrogen free extract for cashew nut shell $(23.62 \%)$ and concentrate (44.53\%) were rather too low, hence sweet potato peels (65.20\%) and Ocimum gratissimum leaves $(69.02 \%)$ would augment the overall energy content of the experimental diets. However, the proximate composition $(\% \mathrm{DM})$ of sweet potato peels, cashew nut shell and Ocimum gratissimum leaves observed in this study were similar to values reported by [4]-[6] respectively.

Growth performance of goats fed experimental diets is indicated in Table 2. All parameters obtained were

Table 1. Proximate composition (\%DM) of sweet potato peels, cashew nut shell, Ocimum gratissium leaves and concentrate.

\begin{tabular}{ccccc}
\hline \multirow{2}{*}{ Parameters } & \multicolumn{3}{c}{ Feeds } \\
\cline { 2 - 5 } & Sweet potato peels & Cashew nut shell & Ocimum gratissium leaves & Concentrate \\
\hline Dry matter & 89.10 & 92.20 & 81.50 & 83.96 \\
Crude protein & 6.40 & 5.50 & 4.43 & 16.15 \\
Crude fibre & 4.00 & 22.75 & 4.20 & 14.25 \\
Ether extract & 6.00 & 39.20 & 2.70 & 1.14 \\
Ash & 7.50 & 1.09 & 1.15 & 7.89 \\
Nitrogen free extract & 65.20 & 23.62 & 69.02 & 44.53 \\
\hline
\end{tabular}

Table 2. Growth performance of goats fed experimental diets.

\begin{tabular}{|c|c|c|c|c|}
\hline \multirow{2}{*}{ Parameters } & \multicolumn{3}{|c|}{ Diets } & \multirow{2}{*}{$\mathrm{SEM} \pm$} \\
\hline & I & II & III & \\
\hline Initial body weight (kg) & 7.98 & 8.12 & 8.22 & 0.05 \\
\hline Final body weight (kg) & $10.96^{\mathrm{b}}$ & $12.01^{\mathrm{a}}$ & $11.01^{\mathrm{b}}$ & 0.02 \\
\hline Av. total weight gain $(\mathrm{kg})$ & $2.98^{\mathrm{b}}$ & $3.89^{\mathrm{a}}$ & $2.79^{\mathrm{b}}$ & 0.06 \\
\hline AV. daily weight gain (kg) & 0.48 & 0.65 & 0.47 & 0.01 \\
\hline Av. total feed intake $(\mathrm{kg})$ & $6.42^{\mathrm{a}}$ & $4.53^{\mathrm{b}}$ & $4.92^{b}$ & 0.08 \\
\hline Feed conversion ratio & $2.15^{\mathrm{a}}$ & $1.17^{\mathrm{b}}$ & $1.96^{\mathrm{a}}$ & 0.03 \\
\hline
\end{tabular}

\footnotetext{
${ }^{a}, \mathrm{~b}$ Mean along the same row with different superscripts are significantly $(\mathrm{P}<0.05)$ different from each other.
} 
significantly $(\mathrm{P}<0.05)$ varied except initial body weight and average daily weight gain that were not differed significantly $(\mathrm{P}>0.05)$. Final body weight was significantly $(\mathrm{P}<0.05)$ differed between dietary treatments with goats on diet II $(12.01 \mathrm{~kg})$ being heavier than those on diet III $(11.01 \mathrm{~kg})$ and diet I $(10.96 \mathrm{~kg})$. Average total weight gain values of $2.98,3.89$ and $2.79 \mathrm{~kg}$ that were obtained for diets I, II and III respectively followed similar trend as observed in final body weight. The observed higher final body weight and average total weight gain on diet II might be as a result of the ability of the goats to properly utilize the diet for body weight gain when compared with either of the two dietary treatments. This is in conformity with the report of [2] that an efficient utilization of nutrients that supply adequate energy and protein is required for optimum growth performance in livestock. Though average daily weight gain values that ranged from 0.47 to $0.68 \mathrm{~kg}$ in the study was not significantly $(\mathrm{P}>0.05)$ influenced between treatment diets, diet II still recorded the highest value compared to diet III and diet I. [14] reported that average daily weight gain depends directly on average total weight gain with the quality of feeds and environmental conditions of the animals.

Average total feed intake values that ranged from 4.53 to $6.42 \mathrm{~kg}$ were significantly $(\mathrm{P}<0.05)$ highest in diet I compared to diet II and III. The different mechanisms involved in determining feed intake allowed the understanding of difference observed in average total intake of feed in this study. Thus, goats on diet I consumed more of the feeds because of the palatability nature and to meet their nutrient requirement than others. This fact confirmed the report of [15] who noted that palatability and nutrient composition of feeds play an important role in regulating fed intake of cane rates. Feed conversion ratio (FCR) that is measured by feed consumed by unit weight gain was not significantly $(\mathrm{P}>0.05)$ affected between values in diet II (1.17) and diet III (1.76) but diet I (2.15) was significantly $(\mathrm{P}<0.05)$ higher than either diet II or III. The marked reduction for feed conversion ratio in diet II indicated a better utilization of the diet and efficiency at which the goats converted the feeds for their body weight gain.

Presented in Table 3 is the haematological parameters of goats fed sweet potato peels and cashew nut shell supplemented with Ocimum gratissimum leaves. The packed cell volume (PCV) of goats on diet II (29.46\%) were significantly $(\mathrm{P}<0.05)$ highest while those on diet III $(24.99 \%)$ were the lowest. However, values of PCV obtained in this study fell within the broad range of values $(24 \%-44 \%)$ recorded for goats [8]. Thus, suggested that the studied goats had tendency for compensatory accelerated of PCV to normal, following an infection or stress. Similarly, haemoglobin $(\mathrm{Hb})$ and red blood cell $(\mathrm{RBC})$ of goats on diet II $\left(10.96 \mathrm{~g} / \mathrm{dl}\right.$ and $\left.9.84 \times 10^{3} / \mathrm{L}\right)$ seem to possess relatively higher $(\mathrm{P}<0.05)$ values compared to diets I $\left(9.83 \mathrm{~g} / \mathrm{dl}\right.$ and $\left.7.96 \times 10^{3} / \mathrm{L}\right)$ and III $(7.03$ $\mathrm{g} / \mathrm{dl}$ and $5.83 \times 10^{3} / \mathrm{L}$ ). Hence $\mathrm{Hb}$ is an advantage in terms of the oxygen carrying capacity to the blood. However, comparison of $\mathrm{Hb}$ and $\mathrm{RBC}$ results in this study with the earlier reports of [8] indicated that $\mathrm{Hb}$ varies proportionately with $\mathrm{RBC}$. This implies that $\mathrm{Hb}$ is beneficial in assessing the RBC status and possibly forecasting the degree of absence of anaemia related diseases.

White blood cell (WBC) has been reported to be a protective system that provide a rapid and potential defence against any infection agent, and also act as the physiological basis for the adaptation of animals to ecological zone that is characterized by high prevalence of diseases [16]. The WBC values observed in this study were generally low and significantly $(\mathrm{P}<0.05)$ influenced by dietary treatments with diet II $\left(4.94 \times 10^{3} / \mathrm{L}\right)$ recording the lowest, followed by diet II $\left(5.61 \times 10^{3} / \mathrm{L}\right)$ before diet I $\left(7.11 \times 10^{3} / \mathrm{L}\right)$ which was the highest. However, the highest value obtained in diet III, suggested a well developed immune system in goats as a result of Ocimum gratissium leaves' supplementation that give such number of immune cells to offer good health. The WBC values obtained in this study fell within the broad range values $\left(4-12.70 \times 10^{3} / \mathrm{L}\right)$ recorded for goats by [8]. Total WBC counts differential measured had significant $(\mathrm{P}<0.05)$ effect on the treatment diets except eosinophils and basophils. The higher neutrophil counts observed in diet III $(49.82 \%)$ further attested the destruction of micro-organism infection or inflammatory diseases in goats [8]. Lymphocytes values of $52.61 \%$, $56.01 \%$ and $47.44 \%$ were obtained for diets I, II and III respectively with diet II recorded the highest and diet I the lowest. This implies that goats on diet II immune system were not impaired; hence they did not react to any infection [17]. Similarly, monocytes was also highest in diet II (1.06\%) and lowest in diet III (0.64\%). Monocyte counts were lesser than the lymphocyte counts in this study. This finding was in agreement with the reported values of monocytes and lymphocytes for goats by [18].

Eosinophils and basophils play vital role in regulating allergic and inflammatory processes and host defence responses against parasitic infection like helminthiasis and ectoparasitic infestation [7]. The low and non-significant $(\mathrm{P}>0.05)$ difference observed in eosinophils indicated that the experimental goats showed no hypersensitivity reaction to the diets offered to the animals. Thus they did not differ from parasitic infection [19]. Mean- 
while, basophils values for goats in this study that were also very low and ranged from $0.01 \%$ to $0.02 \%$ were similar to the observation of [20] who reported that basophils cells are rare in the blood.

Serum biochemical values of experimental goats are shown in Table 4. Significant $(P<0.05)$ variation were observed for ranged values of total protein $(5.98$ to $7.65 \mathrm{~g} / \mathrm{dl})$, albumin $(2.50$ to $3.58 \mathrm{~g} / \mathrm{dl})$ and globulin $(2.48$ to $4.07 \mathrm{~g} / \mathrm{dl}$ ) with goats on diet II higher than diets I and III. However, the highest values of serum protein components observed in diet II corresponded with the highest average weight gain and haemoglobin for goats on the same diet II. This could be attributed to the degree of protein utilization in the diet compared to diets I and III. Okoruwa et al. [2] reported that nutrient utilization by animals have a direct link with the live-weight gain and haematological indices of that same animals. Triglyceride values of 2.02, 2.29 and $1.56 \mathrm{mmol} / \mathrm{L}$ were obtained for diets I, II and III respectively, with diets I and II significantly $(\mathrm{P}<0.05)$ higher than diet III. The difference in physiological and nutritional status of the goats might be responsible for this disparity. Cholesterol of the experimental goats were not comparable across the treatment groups, indicating that increased in cashew nut shell with decrease in sweet potato peels inclusion level in the diets affect the resulting cholesterol content of the goats negatively. The least serum creatinine levels $(\mathrm{P}<0.05)$ were recorded for diets I $(0.89 \mathrm{mg} / \mathrm{dl})$ and II $(0.97$ $\mathrm{mg} / \mathrm{dl})$ while the highest was obtained in diet III $(1.59 \mathrm{mg} / \mathrm{dl})$. It could be observed that the serum creatinine levels observed in this study were inversely proportional to the triglyceride levels of the experimental goats. The reason for this difference was unknown. The serum cholesterol, triglyceride and creatinine values obtained in this work were in line with the finding of [18] for goats. The significant $(\mathrm{P}<0.05)$ higher level of serum urea observed in diet III $(18.29 \mathrm{mg} / \mathrm{dl})$ compared to those in diets II $(11.21 \mathrm{mg} / \mathrm{dl})$ and I $(10.34 \mathrm{mg} / \mathrm{dl})$ had been attributed to excessive tissue protein catabolism associated with not efficiency utilization of protein in the diet. This fact also confirmed the lowest serum protein components observed in the same diet III. This is in consonance with the report of [2] who reported that serum urea levels of animals have inverse proportional to the serum total

Table 3. Haematological parameters of goats fed sweet potato peels and cashew nut shell supplemented with Ocimum gratissium leaves.

\begin{tabular}{|c|c|c|c|c|}
\hline \multirow{2}{*}{ Parameters } & \multicolumn{3}{|c|}{ Diets } & \multirow{2}{*}{$\mathrm{SEM} \pm$} \\
\hline & I & II & III & \\
\hline PCV (\%) & $26.03^{\mathrm{b}}$ & $29.46^{\mathrm{a}}$ & $24.99^{\mathrm{c}}$ & 0.32 \\
\hline $\mathrm{Hb}(\mathrm{g} / \mathrm{dl})$ & $9.83^{\mathrm{a}}$ & $10.96^{\mathrm{a}}$ & $7.03^{\mathrm{b}}$ & 0.53 \\
\hline $\mathrm{RBC}\left(\times 10^{3} / \mathrm{L}\right)$ & $7.96^{\mathrm{b}}$ & $9.84^{\mathrm{a}}$ & $5.83^{\mathrm{c}}$ & 0.42 \\
\hline WBC $\left(\times 10^{3} / \mathrm{L}\right)$ & $8.01^{\mathrm{b}}$ & $5.94^{\mathrm{c}}$ & $10.11^{\mathrm{a}}$ & 0.77 \\
\hline Neutrophils (\%) & $46.67^{\mathrm{b}}$ & $38.11^{\mathrm{c}}$ & $49.82^{\mathrm{a}}$ & 1.07 \\
\hline Lymphocytes (\%) & $52.61^{\mathrm{a}}$ & $56.01^{\mathrm{a}}$ & $47.44^{\mathrm{c}}$ & 1.43 \\
\hline Monocytes (\%) & $0.71^{\mathrm{b}}$ & $1.06^{\mathrm{a}}$ & $0.64^{\mathrm{b}}$ & 0.02 \\
\hline Eosinophils (\%) & 1.62 & 1.34 & 1.72 & 0.04 \\
\hline Basophils (\%) & 0.02 & 0.01 & 0.02 & 0.01 \\
\hline
\end{tabular}

\footnotetext{
${ }^{a, b}, c$ Mean in the same row with different superscripts are significantly different $(\mathrm{P}<0.05)$.
}

Table 4. Serum biochemical parameters of goats fed experimental diets.

\begin{tabular}{|c|c|c|c|c|}
\hline \multirow{2}{*}{ Parameters } & \multicolumn{3}{|c|}{ Diets } & \multirow{2}{*}{$\mathrm{SEM} \pm$} \\
\hline & I & II & III & \\
\hline Total protein $(\mathrm{g} / \mathrm{dl})$ & $6.01^{\mathrm{b}}$ & $7.65^{\mathrm{a}}$ & $5.98^{\mathrm{b}}$ & 0.71 \\
\hline Albumin (g/dl) & $2.50^{\mathrm{b}}$ & $3.58^{\mathrm{a}}$ & $3.50^{\mathrm{a}}$ & 0.10 \\
\hline Globulin (g/dl) & $3.51^{\mathrm{b}}$ & $4.07^{\mathrm{a}}$ & $2.48^{\mathrm{c}}$ & 0.21 \\
\hline Triglyceride $(\mathrm{mmol} / \mathrm{L})$ & $2.03^{\mathrm{b}}$ & $2.29^{\mathrm{a}}$ & $1.56^{\mathrm{b}}$ & 0.32 \\
\hline Cholesterol $(\mathrm{mmol} / \mathrm{L})$ & $22.44^{\mathrm{c}}$ & $31.34^{\mathrm{b}}$ & $42.34^{\mathrm{a}}$ & 1.42 \\
\hline Creatinine $(\mathrm{Mg} / \mathrm{dl})$ & $0.89^{\mathrm{b}}$ & $0.97^{\mathrm{b}}$ & $1.59^{\mathrm{a}}$ & 0.02 \\
\hline Urea $(\mathrm{Mg} / \mathrm{dl})$ & $10.34^{\mathrm{b}}$ & $11.21^{\mathrm{b}}$ & $18.29^{\mathrm{a}}$ & 1.15 \\
\hline
\end{tabular}

\footnotetext{
${ }^{\mathrm{a}, \mathrm{b}, \mathrm{c}}$ Mean in the same row with different superscripts are significantly different $(\mathrm{P}<0.05)$.
} 
protein of the animal.

\section{Conclusion}

The results obtained in the present study confirm a positive effect of using sweet potato peels and cashew nut shell with Ocimum gratissimum leaves' supplementation as feeds for goats. The response in terms of growth indices and blood constituents by goats shows that diet II can serve as a sustainable feed that will overcome dry season weight losses and poor performance in terms of health wise of the goats compared with either diet I or III.

\section{References}

[1] Ibitoye, E.B., Olorede, B.R., Jimoh, A.A. and Suleiman, N. (2010) The Rabbit Industry and Alternative Feedstuffs: A Review. Proceedings of 35th Conference of Nigerian Society for Animal Production, University of Ibadan, Ibadan, 207-211.

[2] Okoruwa, M.I., Adewumi, M.K. and Igene, F.U. (2013) Thermophysiology Responses of West African Dwarf Bucks Fed Pennisetum purpureum and Unripe Plantain Peels. Nigerian Journal of Animal Science, 15, 168-178.

[3] Ahamefule, F.O. and Udo, M.D. (2010) Performance of West African Dwarf Goats Fed Raw or Processed Pigeon Pea (Cajanus cajan) Seed Meal Based Diets. Nigerian Journal of Animal Science Production, 37, 227-236.

[4] Malik, A.A., Kudu, Y.S., Ibrahim, M.J., Agunbiade, A.A. and Oyedepo, M.T. (2011) Performance of Growing Rabbits Fed Graded Levels of Sweet Potato (Ipomea batatas) Peel Meal Diets Supplemented with and without Molasses. Proceedings of 36th Conference of Nigerian Society for Animal Production, University of Abuja, Abuja, 180-184.

[5] Okolo, F.A.I., Ocheja, J.O.I., Lalabe, B.C.I. and P.A. (2012) Digestibility, Performance and Bio-Economics of Growing west African Dwarf Goats Fed Diets Containing Graded Levels of Cashew Nut Shell. International Journal of Agriculture and Rural Development, 15, 1000-1007.

[6] Effiong, E.E. (2014) Phytochemical, Proximate, Vitamins and Minerals Composition of Ocimum gratissium Leaves. Journal of Physical and Chemical Science, 14, 15297-15304.

[7] Byanet, O., Adamu, S., Salami, S.O. and Obadiah, H.I. (2008) Haematological and Plasma Biochemical Parameters of the Young Grasscutter (Thyronomys swinderianus) Reared in Northern Nigeria. Journal of Cell and Animal Biology, 2, 177-181.

[8] Opara, M.N., Udevi, N. and Okoli, I.C. (2010) Haematological Parameters an Blood Chemistry of Apparently Healthy West African Dwarf (WAD) Goats in Owerri, South-Eastern Nigeria. New York Science Journal, 3, 68-72.

[9] AOAC (2002) Official Method of Analysis. 16th Edition, Association of Official Analytical, Washington DC.

[10] SAS (2003) Statistical Analysis System User's Guide: Statistical Version. 8th Edition, SAS Institute, Cary.

[11] ARC (Agricultural Research Council) (1984) The Nutrient Requirements of Livestock. Commonwealth Agricultural Bureaux, Slough.

[12] Ocheja, J.O., Aduku, A.O., Okolo, F.A., Ikughiyi, M.A., Sule, A. and Mamah, M.(2011) Proximate Composition and Mineral Profile of Cashew Nut Shell; Implication for Ruminant Animal production. Proceedings of the 16th Annual Conference of the Animal Science Association of Nigeria, 479-482.

[13] Anabarasu, C., Dulta, N., Sharma, K. and Rawat, M. (2004) Response of Goats to Partial Replacement of Dietary Protein by a Leaf Mixture Containing Leucaena leucophala, Morus alba and Tectona grandis. Small Ruminant Research, 51, 45-56.

[14] Sahlu, T., Goetsch, A.L., Luo, J., Nsahlai, I.V., Moare, J.E., Galyean, M.I., Owens, F.N., Ferrel, C.L. and Johnson, Z.B. (2004) Nutrient Requirements of Goats: Developed Equations Other Consideration and Future Research to Improve Them. Small Ruminant Research, 53, 191-219.

[15] Taiwo, A.A., Fayenuwo, J.O., Omole, A.J., Fayimi, A.K., Fapohunda, J.B. and Adebowale, E.A. (2009) Supplementary Effect of Concentrate Feed on the Performance of Cane Rats Fed a Basal Diet of Elephant Grass. Nigerian Journal of Animal Production, 36, 153-160.

[16] Adesehinwa, A.O.K., Obi, O.O., Makanjuola, B.A., Oluwole, O.O. and Adesina, M.A. (2011) Growing Pigs Fed Cassava Peel Based Diet Supplemented with or without Farmazyme 3000 Proenx: Effect on Growth, Carcass and Blood Parameters. African Journal of Biotechnology, 10, 2791-2796.

[17] Konlan, S.P., Karikari, P.K. and Ansah, T. (2012). Productive and Blood Indices of Dwarf Rams Fed a Mixture of Rice Straw and Groundnut Haulms Alone or Supplemented with Concentrates Containing Different Levels of Shea Nut Cake. Pakistan Journal of Nutrition, 11, 566-571. http://dx.doi.org/10.3923/pjn.2012.566.571

[18] Ikhimioya, I. and Imasuen, J.A. (2007) Blood Profile of West African Dwarf Goats Fed Pancium maximum Supple- 
mented with Ajzelia africana and Newbouldia laevis. Pakistan Journal of Nutrition, 6, 79-84. http://dx.doi.org/10.3923/pjn.2007.79.84

[19] AACC (American Association for Clinical Chemistry) (2011) White Blood Cell Differential Count. http://labtestsonline.org/understanding/analystes/differential/tab/test

[20] Ogunsanmi, A.O., Ozegbe, P.C., Ogunjobi, O., Taiwo, V.O. and Adu, J.O. (2002) Haematological, Plasma Biochemistry and Whole Blood Minerals of the Captive Adult African Grasscutter (Thryonomys swinderianus). Tropical Veterinarian, 20, 27-34. http://dx.doi.org/10.4314/tv.v20i1.4506 